\title{
STUDIES IN IRON TRANSPORTATION AND METABOLISM. I. CHEMICAL METHODS AND NORMAL VALUES FOR PLASMA IRON AND "EASILY SPLIT-OFF" BLOOD IRON
}

\author{
By CARL V. MOORE, 1 With the technical assistance of WM. R. ARROWSMITH, \\ J. J. QUILLIGAN, JR. AND J. T. READ \\ (From the Department of Medicine, Division of Research Medicine, Ohio State \\ University, Columbus)
}

(Received for publication March 11, 1937)

Iron is now recognized in three forms in the blood : hemoglobin iron, plasma iron, and " easily split-off" iron. The last has been so termed because weak acids readily free it from its lightly bound state in the erythrocytes and in plasma. Barkan (1), Lintzel (2), Starkenstein and Weden (3), Dominici (4), and others $(5,11)$ have gone far toward defining this "leicht abspaltbare Bluteisen" fraction, and Barkan has demonstrated that it may be subdivided into two parts: E, comprising about 60 to 70 per cent of the whole and present only in the erythrocytes, is bound by carbon monoxide in such a manner that it is protected against the "splitting-off" action of weak acids; and $\mathrm{E}^{\prime}$, constituting about 30 to 40 per cent of the fraction and present in plasma as well as in the red cells, is not bound by carbon monoxide. In addition to these three forms, iron is also present in the nuclei of the leukocytes in minute amounts comparable to those found by Warburg in practically all cells of the body as a part of the respiratory enzyme mechanism.

Plasma iron and "easily split-off" iron have been the subject of many recent investigations in an attempt to determine their physiological significance. Progress in this direction has been delayed primarily because the small amounts of iron present in these two fractions are difficult to determine. Most of the earlier techniques lack accuracy and dependability. The amount of hemoglobin iron is so many times greater than the amounts of non-hemoglobin iron in blood that it is difficult sharply to separate the one from the other. Normal values reported by different investigators for plasma and for " easily split-off " blood iron have shown wide variations. Consequently, a skeptical attitude, not entirely unjusti-

1 These studies were begun during the tenure of a $\mathrm{Na}$ tional Research Council Fellowship in the Department of Medical and Surgical Research, Ohio State University. fied, has arisen concerning the very existence and independent identity of the non-hemoblogin iron fractions.

The present series of studies has been directed toward a better understanding of the mechanism and significance of iron transportation and utilization. A knowledge of the normal zonal range for the plasma and " easily split-off" blood iron fractions with an accurate measure of the dependability of the methods used in determining them is fundamental. This communication, therefore, will attempt to analyze critically the methods of quantitation that have been used in the past; will present certain changes in technique, which have been found of help in establishing the dependability of the chemical analyses; and from original data accumulated in this laboratory, and from the literature, will suggest the limits for the range of normal variation.

\section{A. PLASMA AND SERUM IRON}

\section{The non-hemoglobinous nature of plasma iron}

Because it has been extremely difficult to measure quantitatively the minute amounts of hemoglobin due to hemolysis which may be present in blood plasma or serum, there has been considerable hesitancy about accepting the small amounts of iron found in plasma as really of non-hemoglobinous origin. Whole human blood contains approximately $50 \mathrm{mgm}$. per cent hemoglobin iron, a quantity of iron 500 times greater than the amounts reported by most observers as occurring in normal plasma (range 50 to 180 micrograms per cent). The erythrocytes from which the plasma or serum samples are separated must necessarily be subjected to the trauma which always accompanies venesection and centrifugation so that some hemolysis is almost unavoidable; and only 18 to $51 \mathrm{mgm}$. per cent hemoglobin needs be present in plasma to account for all the iron nor- 
mally found. It will be apparent, however, that abundant experimental evidence exists upon which to establish plasma iron as a non-hemoglobinous form of iron.

Henriques and Roche (6), Marlow and Taylor (7), and others examined plasma and serum samples spectroscopically for the absorption bands of oxyhemoglobin before making their determinations. Henriques and Roche (6) found spectroscopic methods capable of detecting 3 to $5 \mathrm{mgm}$. per cent hemoglobin (10 to 16.5 micrograms per cent hemoglobin iron). By adding to their sera a known amount of hemoglobin and rediluting with graduated dilutions until the absorption bands of oxyhemoglobin just faded out, they were able to quantitate the amount of hemoglobin present within a stated accuracy of 10 per cent and to prove that only a fraction of the iron present in the samples analyzed by them was hemoglobin iron.

Fowweather (8), by drawing blood very carefully into an oiled syringe, transferring it promptly to a paraffined tube and centrifuging immediately at high speed, was able to throw the blood platelets down with the other formed elements of blood before coagulation began. The plasma thus obtained contained no anticoagulant and gave a negative benzidine reaction with a benzidine reagent whose sensitivity was such that it could detect one part per million of hemoglobin (less than 1 microgram per cent hemoglobin iron). Bing and Hanzal (9), working with dog blood, were unable to duplicate Fowweather's results and again considered it necessary to find some way of measuring the amounts of hemoglobin present in the plasma or serum with which they were working. They devised a colorimetric method based on the color formed with benzidine; but because of the proteins present in plasma and serum, only about 75 per cent of a known amount of added hemoglobin could be recovered. Hence, on each set of determinations a factor of recovery had to be determined and all results corrected accordingly.

By slightly modifying Fowweather's method, we have been able to obtain with fair consistency human sera, ${ }^{2}$ which contained less than 1 micro-

\footnotetext{
2 The term " serum," rather than "plasma," is used advisedly. The speed at which blood was centrifuged
}

gram per cent of hemoglobin iron. Instead of using an oiled syringe, blood was permitted to flow from an 18 gauge needle directly into a paraffined tube, immediately following which the blood was centrifuged at 2500 r.p.m. for 45 minutes. Occasionally, slight hemolysis occurred, particularly when important blood specimens had to be collected at some distance from the laboratory and immediate centrifugation was impossible. Under such circumstances, a quantitative determination of the hemoglobin iron present in the serum became necessary. The following method, based on the benzidine-hemoglobin color reaction, was accordingly devised.

Crystalline benzidine dihydrochloride was prepared according to the method of Leiboff (10). One cc. of a freshly prepared 1 per cent aqueous solution of this reagent was placed in a glass comparator tube (vial $11 \times 2 \mathrm{~cm}$.) along with varying quantities of dilute hemoglobin solutions of known concentration and the volume made up to $10 \mathrm{cc}$. with distilled water. To this was added $1 \mathrm{cc}$. of 3 per cent hydrogen peroxide, and the whole observed for the development of the characteristic blue color reaction. Two blanks for comparison were similarly prepared, one with the hemoglobin solution omitted, and the other with no hydrogen peroxide added. Since the color gradually developed to its maximum intensity and then immediately began to fade, comparison in a colorimeter was not practical. The comparator tubes, instead, were observed through the depth of the fluid against a white background, daylight being used as the source of light, and the smallest amount of hemoglobin ( 0.2 to 0.4 microgram under these circumstances) which would just develop a perceptible color with the benzidine reagent was determined. In a similar manner, the smallest quantity of any particular serum or plasma preparation which would just give a perceptible color with the benzidine was noted. The hemoglobin iron content could then be calculated in the following manner:
(a) $S \times \frac{100}{q}=\mu \mathrm{g}$ per cent hemoglobin in serum,
(b) $\mu \mathrm{g}$ per cent hemoglobin in serum $\times 0.334$ per cent (Butterfield's factor) (37) $=\mu \mathrm{g}$ per cent hemoglobin iron in serum,

was evidently not great enough to throw the platelets down with the other formed elements. After 15 to 20 minutes of centrifugation, therefore, coagulation of the cell-free plasma occurred. The fibrin of the clot, however, was whirled down onto the surface of the packed red and white cells almost as rapidly as it was formed. There it made a white, rubbery, button-like partition between the serum and the underlying cellular elements, and served to keep the red cells from being disturbed while the serum was removed with a pipette. 
where $\mu \mathrm{g}=$ micrograms,

$S=$ micrograms of hemoglobin which reagent was just capable of detecting,

$q=$ smallest quantity of serum which just gave a perceptible color.

Any colorimetric method which uses as its endpoint the smallest amount of any reacting substance which, under given conditions, will just form a perceptible color with a chromophore group is open to obvious objections and to considerable error. The described benzidine method, however, accomplishes the end of demonstrating the fact that only a small amount of the iron present in plasma or serum samples prepared as described is hemoglobin iron. It possesses a special advantage in that it is relatively more accurate in the lower ranges of hemoglobin iron concentration than is either the spectroscopic method of Henriques and Roche (6) or the benzidine method of Bing and Hanzal (9). If, for example, the sensitivity of the benzidine dihydrochloride reagent is 0.3 microgram per cent hemoglobin, and the smallest amount of a particular serum preparation which will just develop a color with it is $0.1 \mathrm{cc}$., then the hemoglobin iron concentration of that serum is only 1 microgram per cent. For all practical purposes, it matters little whether there is 100 per cent variation from this figure. As the hemoglobin concentration becomes higher, the just detectable color is given by smaller amounts of serum, the denominator in the equation ( $a$ ) above becomes smaller, and the error produced by any error in the reading becomes correspondingly greater. In Table I are presented representative data: 1 , illustrative of the accuracy of the method in recovering known amounts of hemoglobin added to serum, and, 2, comparing figures for hemoglobin iron in intentionally hemolyzed specimens obtained by the benzidine method with those obtained by actually observing the increase in total iron. If the hemoglobin iron concentrations are greater than 40 to 50 micrograms per cent, the method has but little value and spectroscopic methods of quantitation would seem to be more applicable.

The most commonly used method for differentiating between hemoglobin and non-hemoglobin iron in serum eliminates the hemoglobin by precipitating it with trichloracetic acid. The actual iron determination is then made on the proteinfree filtrate of the serum sample being analyzed.
TABLE I

Accuracy of the benzidine method for determination of hemoglobin iron present in serum or plasma

I. Recovery of added known quantities of hemoglobin

\begin{tabular}{|c|c|c|c|c|}
\hline \multirow{2}{*}{$\begin{array}{c}\text { Hemoglobin } \\
\text { iron in serum }\end{array}$} & \multirow{2}{*}{$\begin{array}{l}\text { Hemoglobin } \\
\text { iron added }\end{array}$} & \multicolumn{2}{|c|}{ Total hemoglobin iron } & \multirow{2}{*}{$\begin{array}{l}\text { Total amount } \\
\text { recovered }\end{array}$} \\
\hline & & Calculated & Determined & \\
\hline $\begin{array}{c}\text { micrograms } \\
\text { per cent }\end{array}$ & $\begin{array}{c}\text { micrograms } \\
\text { per cent }\end{array}$ & $\underset{\text { per cent }}{\text { micrograms }}$ & $\underset{\text { per cent }}{\text { micrograms }}$ & $\underset{\text { per cent }}{\text { micrograms }}$ \\
\hline $\begin{array}{l}0.2 \\
0.2 \\
0.2 \\
2.4 \\
2.4 \\
2.4\end{array}$ & $\begin{array}{r}1.2 \\
2.4 \\
9.9 \\
2.3 \\
22.8 \\
45.6\end{array}$ & $\begin{array}{r}1.4 \\
2.6 \\
10.1 \\
4.7 \\
25.2 \\
48.0\end{array}$ & $\begin{array}{r}2.4 \\
2.5 \\
10.0 \\
7.3 \\
16.7 \\
36.5\end{array}$ & $\begin{array}{r}2.2 \\
2.3 \\
9.8 \\
4.9 \\
14.3 \\
34.1\end{array}$ \\
\hline
\end{tabular}

II. Comparison of iron and benzidine determination of hemoglobin iron

\begin{tabular}{|c|c|c|c|c|c|c|c|}
\hline \multirow[b]{2}{*}{$\underset{\text { tient }}{\mathrm{Pa}-}$} & \multirow[b]{2}{*}{$\begin{array}{l}\text { Diag- } \\
\text { nosis }\end{array}$} & \multicolumn{3}{|c|}{$\underset{\text { determination }}{\text { Iron }}$} & \multicolumn{3}{|c|}{$\begin{array}{c}\text { Hemoglobin iron } \\
\text { determination }\end{array}$} \\
\hline & & $\begin{array}{c}\text { Se- } \\
\text { rum }\end{array}$ & $\begin{array}{c}\text { Hemo- } \\
\text { lyzed } \\
\text { se- } \\
\text { rum }\end{array}$ & $\begin{array}{l}\text { Hemo- } \\
\text { globin } \\
\text { iron in- } \\
\text { crease }\end{array}$ & $\begin{array}{l}\text { Se- } \\
\text { rum }\end{array}$ & $\begin{array}{c}\text { Hemo- } \\
\text { lyzed } \\
\text { se- } \\
\text { rum }\end{array}$ & $\begin{array}{l}\text { Hemo- } \\
\text { globin } \\
\text { iron in- } \\
\text { crease }\end{array}$ \\
\hline & & $\left|\begin{array}{c}m g m . \\
\text { per } \\
\text { cent }\end{array}\right|$ & $\begin{array}{c}\text { mgm. } \\
\text { per } \\
\text { cent }\end{array}$ & $\begin{array}{c}\text { mgm. } \\
\text { per } \\
\text { cent }\end{array}$ & $\begin{array}{c}\text { mgm. } \\
\text { per } \\
\text { cent }\end{array}$ & $\begin{array}{c}\text { mgm. } \\
\text { per } \\
\text { cent }\end{array}$ & $\begin{array}{c}\text { mgm. } \\
\text { per } \\
\text { cent }\end{array}$ \\
\hline $\begin{array}{l}\text { A. K. } \\
\text { J. J. Q. } \\
\text { W. A. } \\
\text { W. S. } \\
\text { C. M. } \\
\text { C. M. } \\
\text { J. J. Q. }\end{array}$ & $\begin{array}{l}\text { Polycythemia } \\
\text { "Normal"" } \\
\text { "Normal" } \\
\text { Treated P.; A. } \\
\text { "Norma", } \\
\text { "Normal" } \\
\text { After hemor- }\end{array}$ & $\left|\begin{array}{l}0.036 \\
0.117 \\
0.113 \\
0.069 \\
0.137 \\
0.095 \\
0.063\end{array}\right|$ & $\begin{array}{l}0.054 \\
0.144 \\
0.201 \\
0.131 \\
0.512 \\
0.102 \\
0.088\end{array}$ & $\begin{array}{l}0.018 \\
0.027 \\
0.088 \\
0.062 \\
0.375 \\
0.007 \\
0.025\end{array}$ & $\begin{array}{r}0.006 \\
<0.001 \\
<0.001 \\
<0.001 \\
<0.001 \\
<0.001 \\
<0.003\end{array}$ & $\begin{array}{l}0.029 \\
0.036 \\
0.092 \\
0.063 \\
0.391 \\
0.012 \\
0.017\end{array}$ & $\begin{array}{l}0.023 \\
0.036 \\
0.092 \\
0.063 \\
0.391 \\
0.012 \\
0.014\end{array}$ \\
\hline L. $\mathbf{R}$. & $\begin{array}{l}\text { Iron de- } \\
\text { ficiency }\end{array}$ & $|0.046|$ & 0.072 & 0.026 & $<0.001$ & 0.048 & 0.048 \\
\hline
\end{tabular}

As pointed out by Fowweather (8) and Tompsett (11), however, appreciable quantities of true serum iron are carried down with the trichloracetic acid precipitate, probably by a process of coprecipitation, and values so obtained are correspondingly low. The data presented in Tables II and III substantiate Fowweather's conclusions. Iron determinations were made according to the method described later in this paper. Proteinfree filtrates of serum were prepared by adding 3 parts of water to 1 part of serum and then 1 part of a 20 per cent aqueous solution of redistilled trichloracetic acid, permitting the whole to stand for 15 minutes, and then centrifuging at high speed until the precipitate was well packed. By substituting varying amounts of a standard iron solution $(0.1 \mathrm{mgm}$. per cent iron as ferric chloride) for equal amounts of the water portion, it was possible to establish (Table III) the fact that a definite amount of added iron was also carried down with or trapped by the protein precipitate. 
TABLE II

Recovery of serum iron after precipitation of proteins with trichloracetic acid

\begin{tabular}{|c|c|c|c|c|c|}
\hline \multirow[t]{2}{*}{ Subject } & \multirow{2}{*}{$\begin{array}{l}\text { Total } \\
\text { iron in } \\
\text { serum }\end{array}$} & \multirow{2}{*}{$\begin{array}{l}\text { Hemo- } \\
\text { globin } \\
\text { iron } \\
\text { in } \\
\text { serum }\end{array}$} & \multirow{2}{*}{$\begin{array}{l}\text { Non- } \\
\text { hemo- } \\
\text { globin } \\
\text { serum } \\
\text { iron }\end{array}$} & \multicolumn{2}{|c|}{$\begin{array}{l}\text { Serum iron } \\
\text { recovered in } \\
\text { trichloracetic } \\
\text { acid } \\
\text { filtrates }\end{array}$} \\
\hline & & & & Amount & $\begin{array}{l}\text { Recov- } \\
\text { ered }\end{array}$ \\
\hline \multirow{10}{*}{ 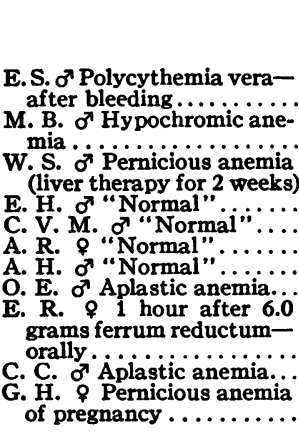 } & $\underset{\substack{\text { per } \\
\text { cent }}}{\operatorname{mgm} .}$ & $\underset{\substack{\text { per } \\
\text { cent } \\
\text { mgm. }}}{ }$ & $\begin{array}{c}\text { mgm. } \\
\text { per } \\
\text { cent }\end{array}$ & $\underset{\substack{\text { per } \\
\text { cent }}}{\operatorname{mgm} .}$ & $\begin{array}{l}\text { per } \\
\text { cent }\end{array}$ \\
\hline & 0.039 & & $\begin{array}{l}c e n t \\
0.039\end{array}$ & $\begin{array}{c}\text { cent } \\
0.026\end{array}$ & 66.7 \\
\hline & 0.029 & $<0.001$ & 0.029 & 0.024 & 82.8 \\
\hline & 0.0 & $<0001$ & 0057 & 0047 & \\
\hline & 0.065 & $<0.001$ & 0.065 & 0.052 & $\begin{array}{l}82.5 \\
80.0\end{array}$ \\
\hline & $\begin{array}{l}0.120 \\
0.135\end{array}$ & $<0.001$ & $\begin{array}{l}0.126 \\
0.135\end{array}$ & $\begin{array}{l}0.101 \\
0.127\end{array}$ & $\begin{array}{l}80.1 \\
94.8\end{array}$ \\
\hline & $\begin{array}{l}0.126 \\
0.163\end{array}$ & $\begin{array}{r}<0.001 \\
0.002\end{array}$ & $\begin{array}{l}0.126 \\
0.161\end{array}$ & $\begin{array}{l}0.108 \\
0.124\end{array}$ & $\begin{array}{l}85.7 \\
77.0\end{array}$ \\
\hline & & & & & \\
\hline & $\begin{array}{l}0.185 \\
0.300\end{array}$ & $\begin{array}{r}<0.001 \\
0.004\end{array}$ & $\begin{array}{l}0.185 \\
0.296\end{array}$ & $\begin{array}{l}0.121 \\
0.211\end{array}$ & $\begin{array}{l}\mathbf{6 5 . 4} \\
71.3\end{array}$ \\
\hline & 0.274 & 0.004 & 0.270 & 0.191 & 69.9 \\
\hline
\end{tabular}

TABLE III

Effect of trichloracetic acid precipitation on recovery of known amounts of iron added to serum

\begin{tabular}{|c|c|c|c|c|c|c|c|}
\hline \multirow{2}{*}{ Subject } & \multirow{2}{*}{$\begin{array}{l}\text { Non- } \\
\text { hemo- } \\
\text { globin } \\
\text { gerum } \\
\text { iron }\end{array}$} & \multicolumn{2}{|c|}{$\begin{array}{l}\text { Serum iron } \\
\text { recovered from } \\
\text { trichloracetic } \\
\text { acid filtrate }\end{array}$} & \multirow{2}{*}{$\begin{array}{l}\text { Iron } \\
\text { ad- } \\
\text { ded }\end{array}$} & \multirow{2}{*}{$\begin{array}{l}\text { Total } \\
\text { Iron } \\
\text { deter- } \\
\text { mined } \\
\text { in } \\
\text { fil- } \\
\text { trate }\end{array}$} & \multicolumn{2}{|c|}{$\begin{array}{l}\text { Added tron } \\
\text { recovered }\end{array}$} \\
\hline & & Amount & $\begin{array}{l}\text { Re- } \\
\text { cov- } \\
\text { ery }\end{array}$ & & & Amount & $\begin{array}{l}\text { Re- } \\
\text { cov- } \\
\text { ery }\end{array}$ \\
\hline & $\begin{array}{l}\text { mom. } \\
\text { per } \\
\text { cent }\end{array}$ & $\begin{array}{l}\text { mgm. } \\
\text { per } \\
\text { cent }\end{array}$ & $\begin{array}{l}\text { per } \\
\text { cent }\end{array}$ & $\begin{array}{c}\text { mom. } \\
\text { per } \\
\text { cent }\end{array}$ & $\begin{array}{c}\text { mom. } \\
\text { per } \\
\text { cent }\end{array}$ & $\begin{array}{l}\underset{\text { per }}{\operatorname{mom}} \\
\text { cent }\end{array}$ & $\begin{array}{c}\text { per } \\
\text { cent }\end{array}$ \\
\hline $\begin{array}{l}\text { vera } \\
\text { S' Polycythemia }\end{array}$ & $\begin{array}{l}0.039 \\
0.039 \\
0.039\end{array}$ & $\begin{array}{l}0.026 \\
0.026 \\
0.026\end{array}$ & $\begin{array}{l}67 \\
67 \\
67\end{array}$ & $\begin{array}{l}0.033 \\
0.067 \\
0.133\end{array}$ & $\begin{array}{l}0.058 \\
0.074 \\
0.122\end{array}$ & $\begin{array}{l}0.032 \\
0.048 \\
0.096\end{array}$ & $\begin{array}{l}97 \\
72 \\
72\end{array}$ \\
\hline C. V. M. ఠ" "Normal" & 0.095 & 0.083 & 87 & 0.100 & 0.171 & 0.088 & 88 \\
\hline L. K. \& "Normal" & $\begin{array}{l}0.124 \\
0.124\end{array}$ & $\begin{array}{l}0.115 \\
0.115\end{array}$ & $\begin{array}{l}93 \\
93\end{array}$ & $\begin{array}{l}0.050 \\
0.200\end{array}$ & $\begin{array}{l}0.157 \\
0.278\end{array}$ & $\begin{array}{l}0.042 \\
0.161\end{array}$ & $\begin{array}{l}84 \\
81\end{array}$ \\
\hline J. J. Q. ఠ’ “Normal” & 0.117 & 0.111 & 95 & 0.050 & 0.155 & 0.044 & 88 \\
\hline C. V. M. $\sigma^{7}$ "Normal” & 0.110 & 0.025 & 86 & 0.100 & 0.168 & 0.073 & 73 \\
\hline $\begin{array}{l}\text { F. F. ơ Pernicious ane } \\
\text { mia in relapee }\end{array}$ & $\begin{array}{l}0.221 \\
0.221\end{array}$ & $\begin{array}{l}0.152 \\
0.152\end{array}$ & $\begin{array}{l}69 \\
69\end{array}$ & $\begin{array}{l}0.050 \\
0.100\end{array}$ & $\begin{array}{l}0.186 \\
0.219\end{array}$ & $\begin{array}{l}0.034 \\
0.067\end{array}$ & $\begin{array}{l}68 \\
67\end{array}$ \\
\hline
\end{tabular}

A critical analysis of these two tables demonstrates that there is no true constancy about the amount of serum iron lost in the precipitation process, and that this quantity may vary from only 5 or 10 per cent to as much as 40 per cent. It is interesting to note that the loss recorded in the values for the two cases of aplastic anemia is comparatively high. The factors which influence the amount of iron lost along with the protein precipitate are, however, not at present apparent.
TABLE IV

Recovery of iron added to serum

\begin{tabular}{|c|c|c|c|c|c|}
\hline $\begin{array}{l}\text { Sub- } \\
\text { ject }\end{array}$ & $\left|\begin{array}{c}\text { Amount } \\
\text { of } \\
\text { serum } \\
\text { digested }\end{array}\right|$ & $\begin{array}{c}\text { Total } \\
\text { iron } \\
\text { in } \\
\text { gerum }\end{array}$ & $\begin{array}{c}\text { Iron } \\
\text { added } \\
\text { as } \\
\text { ferric } \\
\text { chlo- } \\
\text { ride* }\end{array}$ & $\begin{array}{l}\text { Total } \\
\text { iron } \\
\text { deter- } \\
\text { mined }\end{array}$ & $\begin{array}{c}\text { Re- } \\
\text { covery }\end{array}$ \\
\hline & $c c$. & $\begin{array}{c}\text { mgm. } \\
\text { per } \\
\text { cent }\end{array}$ & $\begin{array}{c}\text { mgm. } \\
\text { per } \\
\text { cent }\end{array}$ & $\begin{array}{c}\text { mgm. } \\
\text { per } \\
\text { cent }\end{array}$ & $\begin{array}{l}\text { per } \\
\text { cent }\end{array}$ \\
\hline Pernicious anemia $\$$ & & & & & \\
\hline Hypochromic anemia & 10 & 0.051 & 0.050 & 0.108 & 100 \\
\hline 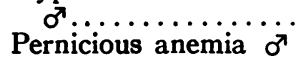 & 10 & 0.028 & 0.100 & 0.128 & 100 \\
\hline (early remission) & 10 & 0.040 & 0.200 & 0.237 & 99 \\
\hline Normal ơ. & 10 & 0.117 & 0.050 & 0.167 & 100 \\
\hline Normal ơ & 10 & 0.095 & 0.100 & 0.197 & 102 \\
\hline Normal o $0^{7}$ & 10 & 0.095 & 0.200 & 0.288 & 97 \\
\hline Normal o $\sigma^{\top}$. & 10 & 0.158 & 0.050 & 0.206 & 97 \\
\hline Aplastic anemia $\sigma^{7}$. & 5 & 0.200 & 0.100 & 0.299 & 99 \\
\hline Aplastic anemia $\sigma^{7}$ & 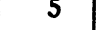 & 0.200 & 0.200 & 0.403 & 102 \\
\hline
\end{tabular}

* Iron added as a solution of ferric chloride (prepared from standard iron wire) which contained $0.100 \mathrm{mgm}$. per cent iron. Thus, to add $\mathbf{0 . 0 5 0} \mathrm{mgm}$. per cent iron to 10 cc. serum, 5 cc. of the iron solution was added; or to add $0.100 \mathrm{mgm}$. per cent iron to $10 \mathrm{cc}$. serum, $10 \mathrm{cc}$. of the iron solution was added; or to add $0.200 \mathrm{mgm}$. per cent iron to $10 \mathrm{cc}$. serum, $20 \mathrm{cc}$. of the iron solution was added.

TABLE V

Serum iron determinations on "normal" adults

\begin{tabular}{|c|c|c|c|c|c|c|c|c|c|}
\hline \multicolumn{5}{|c|}{ Males } & \multicolumn{5}{|c|}{ Females } \\
\hline \multirow{2}{*}{ 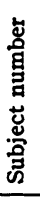 } & \multirow[b]{2}{*}{ 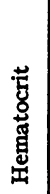 } & \multicolumn{3}{|c|}{ Serum iron } & \multirow{2}{*}{ 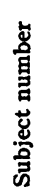 } & \multirow[b]{2}{*}{ 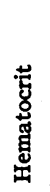 } & \multicolumn{3}{|c|}{ Serum iron } \\
\hline & & $\begin{array}{c}\text { Total } \\
\text { iron } \\
\text { in } \\
\text { se- } \\
\text { rum }\end{array}$ & $\begin{array}{c}\text { Hemo- } \\
\text { globin } \\
\text { iron } \\
\text { in } \\
\text { serum }\end{array}$ & $\begin{array}{l}\text { Non- } \\
\text { hemo- } \\
\text { globin } \\
\text { serum } \\
\text { iron }\end{array}$ & & & $\begin{array}{c}\text { Total } \\
\text { iron } \\
\text { in } \\
\text { se- } \\
\text { rum }\end{array}$ & $\begin{array}{l}\text { Hemo- } \\
\text { globin } \\
\text { iron } \\
\text { in } \\
\text { serum }\end{array}$ & $\begin{array}{c}\text { Non- } \\
\text { hemo- } \\
\text { globin } \\
\text { serum } \\
\text { iron }\end{array}$ \\
\hline \multirow{3}{*}{$\begin{array}{r}1 \\
2 \\
3 \\
4 \\
5 \\
6 \\
7 \\
8 \\
9 \\
10 \\
11 \\
12 \\
13 \\
14 \\
15\end{array}$} & $\begin{array}{l}\text { per } \\
\text { cent }\end{array}$ & $\begin{array}{c}\text { mgm. } \\
\text { per } \\
\text { cent }\end{array}$ & $\begin{array}{c}\text { mgm. } \\
\text { per } \\
\text { cent }\end{array}$ & $\begin{array}{c}\text { per. } \\
\text { pent }\end{array}$ & & $\begin{array}{l}\text { per } \\
\text { cent }\end{array}$ & $\begin{array}{c}\text { mgm. } \\
\text { per } \\
\text { cent }\end{array}$ & $\begin{array}{c}\text { pgm. } \\
\text { pert } \\
\text { cent }\end{array}$ & $\begin{array}{c}\text { mgm. } \\
\text { per } \\
\text { cent }\end{array}$ \\
\hline & $\begin{array}{l}46 \\
44 \\
44 \\
46 \\
45 \\
49 \\
46 \\
46 \\
45 \\
45 \\
48 \\
47 \\
45 \\
45 \\
46\end{array}$ & $\begin{array}{l}0.112 \\
0.098 \\
0.162 \\
0.112 \\
0.126 \\
0.115 \\
0.157 \\
0.126 \\
0.174 \\
0.118 \\
0.096 \\
0.122 \\
0.164 \\
0.115 \\
0.121\end{array}$ & $\begin{array}{r}0.008 \\
<0.001 \\
0.003 \\
0.002 \\
0.032 \\
<0.001 \\
0.024 \\
<0.001 \\
<0.001 \\
<0.001 \\
<0.001 \\
<0.001 \\
<0.001 \\
<0.001 \\
0.026\end{array}$ & $\begin{array}{l}0.104 \\
0.098 \\
0.159 \\
0.110 \\
0.094 \\
0.115 \\
0.133 \\
0.126 \\
0.174 \\
0.118 \\
0.096 \\
0.122 \\
0.164 \\
0.115 \\
0.095\end{array}$ & $\begin{array}{r}1 \\
2 \\
3 \\
4 \\
5 \\
6 \\
7 \\
8 \\
9 \\
10 \\
11 \\
12 \\
13 \\
14 \\
15\end{array}$ & $\begin{array}{l}45 \\
42 \\
45 \\
45 \\
41 \\
44 \\
39 \\
42 \\
42 \\
43 \\
44 \\
42 \\
42 \\
43 \\
43\end{array}$ & $\begin{array}{l}0.119 \\
0.110 \\
0.087 \\
0.120 \\
0.093 \\
0.114 \\
0.124 \\
0.108 \\
0.145 \\
0.065 \\
0.058 \\
0.083 \\
0.085 \\
0.114 \\
0.099\end{array}$ & $\begin{array}{r}<0.001 \\
0.028 \\
<0.001 \\
<0.001 \\
<0.001 \\
0.016 \\
<0.001 \\
<0.001 \\
0.003 \\
<0.001 \\
<0.001 \\
0.003 \\
<0.001 \\
<0.001 \\
<0.001\end{array}$ & $\begin{array}{l}0.119 \\
0.072 \\
0.087 \\
0.120 \\
0.093 \\
0.098 \\
0.124 \\
0.108 \\
0.142 \\
0.065 \\
0.058 \\
0.080 \\
0.085 \\
0.114 \\
0.099\end{array}$ \\
\hline & & \multicolumn{2}{|c|}{$\begin{array}{l}\text { Maximum } \\
\text { Minimum } \\
\text { Average }\end{array}$} & $\begin{array}{l}0.174 \\
0.094 \\
0.1215\end{array}$ & & & \multicolumn{2}{|c|}{$\begin{array}{l}\text { Maximum } \\
\text { Minimum } \\
\text { Average }\end{array}$} & $\begin{array}{l}0.142 \\
0.058 \\
0.0976\end{array}$ \\
\hline
\end{tabular}

Barkan $(1, g)$ showed that the iron in serum or plasma is not ultrafiltrable, but that it is made so when acidified with weak hydrochloric acid. $\mathrm{He}$ incubated the acidified plasma for 24 hours at $37.5^{\circ} \mathrm{C}$. and then submitted it to a process of 
TABLE VI

Iron content of human serum or plasma

\begin{tabular}{|c|c|c|c|c|}
\hline Investigators & Material used & Subjects & $\begin{array}{c}\text { Num- } \\
\text { ber }\end{array}$ & Results \\
\hline $\begin{array}{l}\text { 1. Starkenstein and Weden }(3) \ldots \ldots \\
\text { 2. Riecker }(21 a) \ldots \ldots \ldots \\
\text { 3. Marlow and Taylor }(7) \ldots \ldots \ldots \\
\text { 4. Warburg and Krebs }(19) \ldots \ldots \ldots \\
\text { 5. Langer }(22) \ldots \ldots \\
\text { 6. Guthmann, Brückner, Ehren- } \\
\text { stein and Wagner }(23) \ldots \ldots \ldots \\
\text { 7. Locke, Main and Rosbash }(24) \ldots \\
\text { 8. Barkan }(1 g) \ldots \ldots \ldots \ldots \\
\text { 9. Fowweather }(8) \ldots \ldots \ldots \ldots \\
\text { 10. Tompsett (11) } \ldots \ldots \ldots \ldots \\
\text { 11. Thoenes and Aschaffenburg }(25)\end{array}$ & $\begin{array}{l}\text { Protein free serum (trichloracetic acid) } \\
\text { Protein free serum (trichloracetic acid) } \\
\text { Protein free serum (defibrinated; trichlor- } \\
\text { acetic acid) } \\
\text { Whole serum. Catalytic method } \\
\text { Protein free serum (trichloracetic acid) } \\
\text { Whole serum (ultrafiltration) } \\
\text { Protein free serum (trichloracetic acid) } \\
\text { Whole plasma and serum } \\
\text { Hemoglobin free whole plasma } \\
\text { Thiolactic acid-protein free serum } \\
\text { Protein free serum (trichloracetic acid) } \\
\\
\text { Whole serum-ultrafiltration } \\
\text { Whole serum (hemoglobin present quanti- } \\
\text { tated) }\end{array}$ & $\begin{array}{l}\text { Adults } \\
\text { Adults } \\
\text { Adults } \\
\text { Adults } \\
\text { Adults } \\
\text { Men } \\
\text { Women } \\
\text { Men } \\
\text { Women } \\
\text { Adults } \\
\text { Men } \\
\text { Women } \\
\text { Adults } \\
\text { Infants at } \\
\text { birth } \\
\text { Children } \\
\text { 13 days } \\
\text { to } 9 \text { years } \\
\text { Adults } \\
\text { Men } \\
\text { Women }\end{array}$ & $\begin{array}{r}5 \\
40 \\
5 \\
4 \\
4 \\
20 \\
\\
22 \\
26 \\
8 \\
9 \\
15 \\
10 \\
10 \\
10 \\
12 \\
60\end{array}$ & \begin{tabular}{l}
\multicolumn{1}{c}{ mgm. per cent } \\
$0.690 *(0.570-0.790)$ \\
$1.110(0.9-1.4)$ \\
$0.400-0.700$ \\
$0.084(0.067-0.116)$ \\
$0.110(0.050-0.180)$ \\
\\
$0.065(0.042-0.098)$ \\
$0.068(0.035-0.098)$ \\
$0.100 \pm 0.015$ \\
$0.077 \pm 0.015$ \\
$0.105 *(0.056-0.140)$ \\
$0.125(0.095-0.180)$ \\
$0.105(0.060-0.156)$ \\
$0.120-0.220$ \\
$0.173(0.134-0.291)$ \\
\\
$0.040-0.196$ \\
0.110 \\
$0.121(0.094-0.174)$ \\
$0.097(0.058-0.142)$
\end{tabular} \\
\hline
\end{tabular}

* Not "normal" subjects.

ultrafiltration. Under these conditions, the iron of the hemoglobin molecule does not become ionizable; and the iron which passes through the filter represents the non-hemoglobin plasma iron. That the values obtained by Barkan with such a method are in close agreement with those obtained by other investigators is apparent from Table VI. We have been able to confirm Barkan's observations by acidifying serum with $0.2 \mathrm{~N}$ $\mathrm{HCl}$ and dialyzing it at body temperature in a cellophane membrane against $0.1 \mathrm{~N} \mathrm{HCl}$ for 48 hours. Values so obtained have agreed remarkably with those arrived at by actual digestion of the whole serum or plasma.

It is, therefore, possible to: 1, prepare serum or plasma which is, for all practical purposes, free of hemoglobin; 2, quantitate small amounts of contaminating hemoglobin iron in serum; 3 , precipitate any contained hemoglobin along with serum proteins with trichloracetic acid; and 4, separate the non-hemoglobin serum iron from any hemoglobin present by ultrafiltration or dialysis after acidification with $0.1 \mathrm{~N} \mathrm{HCl}$. The method of precipitation is open to objection in that a portion of the non-hemoglobin iron is carried down with the protein precipitate, and the re- sultant serum iron values are correspondingly low. With these various methods of eliminating or quantitating hemoglobin iron in serum, the non-hemoglobinous character of the quantities determined by the technique immediately to be described seems to be established.

\section{The determination of plasma and serum iron}

Since only 50 to 180 micrograms of non-hemoglobin iron are normally present in $100 \mathrm{cc}$. of human serum, and since it is frequently not practical to obtain more than 10 to $15 \mathrm{cc}$. of serum for analysis, methods used to quantitate serum iron must be capable of measuring 6 to 10 micrograms or less of the metal. Titrimetric methods of sufficient sensitivity to accomplish this result have so far not been developed, and chief reliance has been placed on colorimetric determinations. Most satisfactory of these, particularly because of the greater intensity of the color developed, is that which depends on the red color of ferric thiocyanate.

The thiocyanate method used in these investigations is a modification of Kennedy's (12) procedure. 
1. All glassware used was washed with concentrated $\mathrm{HCl}$ and rinsed with water redistilled from an all glass West distillation apparatus (13). This double glassdistilled water was used throughout.

2. Reagents used: (a) reagent grade sulfuric acid (Grasselli) ; (b) 30 per cent hydrogen dioxide (Baker); (c) reagent grade nitric acid (Grasselli); (d) iso-amyl alcohol (Merck Blue label); and (e) potassium thiocyanate (Merck Blue label). The trichloracetic acid used for the determinations listed in Tables II and III was distilled under reduced pressure from a modified West distillation unit.

3. Digestion. Either 10 or $15 \mathrm{cc}$ of measured serum were pipetted into a $300 \mathrm{cc}$. Kjeldahl flask along with 5 cc. of concentrated sulfuric acid and digestion carried out over a moderate Bunsen flame. After charring and the usual rapid evolution of $\mathrm{CO}_{2}$ had occurred, the digestion mixture was permitted to cool, 4 to 5 cc. of 30 per cent hydrogen peroxide were added and the mixture again heated. Repeated additions of hydrogen peroxide -9 to $12 \mathrm{cc}$. usually sufficed-were made until the solution became colorless. The flask was then rinsed down with the double glass-distilled water and reheated to insure complete breakdown of the peroxide. Several drops of concentrated nitric acid were added while the sulfuric acid digest mixture was still hot $\left(70\right.$ to $100^{\circ} \mathrm{C}$.), and the whole transferred to a $50 \mathrm{cc}$. glass stoppered volumetric flask.

4. Colorimetric comparison. Twenty cc. aliquot portions of the sample were pipetted into $60 \mathrm{cc}$. cylindrical glass-stoppered separatory funnels and overlaid with 10 cc. iso-amyl alcohol. Five cc. of a 20 per cent $\mathrm{KSCN}$ solution were then blown into the funnels and the mixture immediately shaken. The colored amyl alcohol layer was separated and colorimetrically compared with a similarly prepared iron standard amyl alcohol solution of ferric thiocyanate. Occasionally, clouding of the amyl alcohol occurred, but a second shaking before separation from the aqueous layer always sufficed to obviate this difficulty.

The iron standard was prepared by placing exactly 0.5 gram of reagent iron wire in a one liter volumetric flask calibrated by the United States Bureau of Standards, dissolving it in concentrated $\mathrm{HCl}$ and $\mathrm{HNO}_{3}$ (at room temperature for 2 to 3 days) and then diluting it to volume. Two cc. of this solution diluted to one liter contained $0.1 \mathrm{mgm}$. per cent ferric iron, and varying quantities of it were digested in the manner described above (using comparable amounts of reagents), made up to a $50 \mathrm{cc}$. volume, and $20 \mathrm{cc}$. aliquot portions taken for the preparation of the actual colorimetric standards. Standard solutions of iron which varied in iron content from 0.005 $\mathrm{mgm}$. of iron per $50 \mathrm{cc}$. to $0.05 \mathrm{mgm}$. of iron were kept on hand and that one selected for any particular determination which most closely approximated the iron concentration of the "unknown."

The total amount of iron present in the quantities of reagents used for one analysis varied between 10 and 12 micrograms per cent. Since comparable amounts of re- agents were added to the standards, the error thus introduced was practically negligible except for serum iron concentrations of less than $0.030 \mathrm{mgm}$. per cent.

5. Calculation:

$$
\frac{S}{U} \times \frac{100}{\text { cc. of serum }} \times \mathrm{Fe}=\text { mgm. per cent iron, }
$$

where $S=$ reading of the standard;

$U=$ reading of the unknown;

$\mathrm{Fe}=$ quantity of iron present in $50 \mathrm{cc}$. of the iron standard prepared as described above.

6. Precipitation with trichloracetic acid. For the determination of iron in a trichloracetic acid protein-free filtrate of serum or plasma, 1 part of serum was diluted with 3 parts of water. To this was added 1 part 20 per cent trichloracetic acid with gentle shaking. The mixture was permitted to stand for 15 minutes and the protein precipitate centrifuged down. An aliquot portion of the clear supernatant, protein-free solution was then digested with $\mathrm{H}_{2} \mathrm{SO}_{4}$ and the iron content determined as described under 3,4 and 5 above.

That the iron loss noted in such "filtrates" was due to a process of co-precipitation and not to partial volatilization of the iron as ferric chloride, was apparent from the following experiment. On repeated occasions, $10 \mathrm{cc}$. of serum were placed in a $300 \mathrm{cc}$. Kjeldahl digestion flask along with $30 \mathrm{cc}$. of water and $10 \mathrm{cc}$. of 20 per cent trichloracetic acid, and the whole digested. The amount of iron recovered was always found to be identical with that recovered from the simple digestion of $10 \mathrm{cc}$. of the same serum sample.

The addition of nitric acid to the hot digestion mixture insures the complete oxidation of iron to the ferric state (14). Amyl alcohol was used to extract the iron thiocyanate color in preference to the more volatile ether, acetone, and ethylacetate (16). The red color of iron thiocyanate was found to be stable in amyl alcohol solutions for at least fifteen minutes, so that there was ample time in which to make the colorimetric comparisons. Attention has frequently been called to the necessity for regulating the acidity of the solutions in which the ferric thiocyanate color is developed and from which it is extracted by amyl alcohol or any one of the other extractives just mentioned $(14,15,17)$. However, under the conditions described, it was found that the color developed was constant in an acidity range of from 1 to $5 \mathrm{~N} \mathrm{H}_{2} \mathrm{SO}_{4}$. Furthermore, the quantities of serum or plasma digested were relatively constant and the amount of $\mathrm{H}_{2} \mathrm{SO}_{4}$ used, standardized. The normality of the digestion mixtures after having been diluted to $50 \mathrm{cc}$. has never been found to be outside the limits of 2 to $4 \mathrm{~N}$. 
The accuracy of the method is in part defined in Table IV in which the recovery of known amounts of iron added to serum prior to digestion is recorded. It is apparent that a recovery of 96 to 102 per cent was achieved, an accuracy entirely adequate for the study of plasma and serum iron values in health and in disease.

\section{Normal values for serum or plasma iron}

Determinations of serum iron in various laboratory and domestic animals have been made by Fontès and Thivolle (18), Starkenstein and Weden (3), Henriques and Roche (6), Warburg and Krebs (19), Barkan (1, $d)$, Abderhalden and Möller (20), and others. The observations recorded are not sufficiently numerous to merit tabulation for comparison. In general, the values reported for animals are 50 to 100 per cent higher than the normal human mean.

Part of the reluctance to accept as valid the recent work on non-hemoglobin serum and plasma iron has grown out of the fact that normal levels reported by different investigators, particularly those working with human subjects, have shown as much as 1000 per cent variation. In Table VI, however, in which is presented in summary form the various values for normal human plasma iron so far reported, it is apparent that the results of only three groups of investigators $(3,7,21)$ are out of line with the rest. If these three reports are omitted from consideration, one is impressed with the unanimity of the data presented by the remaining workers, an agreement that is all the more remarkable in that at least four different techniques were employed. ${ }^{3}$ The reasons for the higher figures given in the three dissenting reports listed above are not obvious from a review of the available data. However, the great similarity in the normal zonal ranges obtained by nine groups of investigators constitutes sufficient diverse confirmation, we feel, to permit the following two conclusions: 1 , in normal human subjects, the serum or plasma iron level varies from aproximately 0.050 to $0.180 \mathrm{mgm}$. per cent; and, 2 , the mean value for serum iron in normal males

s 1. The catalytic method of Warburg.

2. The ultrafiltration of serum before digestion.

3. Thiolacetic acid method.

4. Various modifications of the thiocyanate method. is aproximately 0.020 to $0.030 \mathrm{mgm}$. per cent higher than the mean value for normal females. Table $\mathrm{V}$ tabulates the determinations on each of the thirty normal subjects studied by us and summarized in Table VI.

\section{Comparison between plasma and serum iron values}

It is of theoretical interest, as Fowweather has indicated, to compare serum and plasma iron values since there is the possibility that some of the plasma iron may be removed in the clot when serum is formed. We have found that when blood obtained by venipuncture is permitted to run from an 18 gauge needle directly into a paraffined centrifuge tube and immediately centrifuged at 2500 r.p.m., the erythrocytes and leukocytes are packed before coagulation takes place. The plasma, in fact, usually does not coagulate for 15 to 20 minutes; and as the fibrin forms, it is thrown down as a thin layer on top of the formed elements. For the present study, two tubes of blood were collected and centrifugation immediately begun. After 12 minutes, one of the tubes was taken from the centrifuge, the unclotted plasma removed, and $10 \mathrm{cc}$. of it pipetted promptly into a Kjeldahl digestion flask. Coagulation occurred within a few minutes after the transfer, but all of the constituents of the plasma were obviously digested. The second tube was removed from the centrifuge at the end of an hour. Complete coagulation had occurred within this period, and the fibrin had been centrifuged down. A $10 \mathrm{cc}$. quantity of the serum was then removed for digestion. The iron values obtained for these serum and plasma specimens collected simultaneously agree with each other well within the limits of error of the method (Table VII), and demonstrate the fact that no appreciable quantity of iron is removed from plasma when coagulation occurs.

Abderhalden and Möller (20) have raised the question as to whether any iron is added to serum from the cells when whole blood is permitted to coagulate. In order to study this possibility, two tubes of blood were collected from subjects as above described. One of these was immediately centrifuged for 60 minutes and the serum collected in the manner that was routine throughout these studies. The second tube was per- 
TABLE VII

Comparison between serum and plasma iron values

\begin{tabular}{|c|c|c|c|c|c|c|c|}
\hline \multirow[b]{2}{*}{ Subject } & \multicolumn{3}{|c|}{ Whole serum } & \multicolumn{3}{|c|}{ Whole plasms } & \multirow{2}{*}{$\begin{array}{l}\text { Va- } \\
\text { ria- } \\
\text { tion }\end{array}$} \\
\hline & $\begin{array}{c}\text { Total } \\
\text { iron } \\
\text { preas } \\
\text { ent }\end{array}$ & $\begin{array}{c}\text { Hemo- } \\
\text { glo- } \\
\text { bin } \\
\text { iron }\end{array}$ & $\mid \begin{array}{c}\text { Non- } \\
\text { hemo- } \\
\text { lglobin } \\
\text { iron }\end{array}$ & $\begin{array}{c}\text { Total } \\
\text { iron } \\
\text { pres- } \\
\text { ent }\end{array}$ & $\begin{array}{c}\text { Hemo- } \\
\text { glo- } \\
\text { bin } \\
\text { iron }\end{array}$ & \begin{tabular}{|c|} 
Non- \\
hemo- \\
globin \\
iron
\end{tabular} & \\
\hline \multirow{4}{*}{ 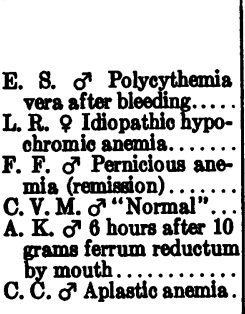 } & $\begin{array}{c}\text { mom. } \\
\text { per } \\
\text { cent }\end{array}$ & $\begin{array}{c}\text { mom. } \\
\text { per } \\
\text { cent }\end{array}$ & $\begin{array}{c}\text { mom. } \\
\text { per } \\
\text { cent }\end{array}$ & $\begin{array}{c}\text { mom. } \\
\text { per } \\
\text { cent }\end{array}$ & $\begin{array}{l}\text { mom. } \\
\text { per } \\
\text { cent }\end{array}$ & $\begin{array}{c}\text { mom. } \\
\text { per } \\
\text { cent } \\
\end{array}$ & $\begin{array}{l}\text { per } \\
\text { cent }\end{array}$ \\
\hline & $\begin{array}{l}0.029 \\
0.054\end{array}$ & $\begin{array}{r}0.002 \\
<0.001\end{array}$ & $\left|\begin{array}{l}0.027 i \\
0.054\end{array}\right|$ & $\begin{array}{l}0.028 \\
0.052\end{array}$ & $\begin{array}{r}0.0015 \\
<0.001\end{array}$ & $\begin{array}{l}0.027 \\
0.052\end{array}$ & $\begin{array}{c}0 \\
-3.8\end{array}$ \\
\hline & $\begin{array}{l}0.119 \\
0.148\end{array}$ & $\begin{array}{l}0.003 \\
0.004\end{array}$ & \begin{tabular}{|l|}
0.116 \\
0.144
\end{tabular} & $\begin{array}{l}0.118 \\
0.140\end{array}$ & $\begin{array}{l}<0.001 \\
<0.001\end{array}$ & \begin{tabular}{|l|}
0.118 \\
0.140
\end{tabular} & $\begin{array}{l}+1.7 \\
-2.8\end{array}$ \\
\hline & \begin{tabular}{|l|}
0.218 \\
0.313
\end{tabular} & $<0.001$ & $\begin{array}{l}0.218 \\
0.311\end{array}$ & $\begin{array}{l}0.223 \\
0.308\end{array}$ & $\begin{array}{r}0.001 \\
<0.001\end{array}$ & $\begin{array}{l}0.222 \\
0.308\end{array}$ & $\begin{array}{l}+1.8 \\
-0.9\end{array}$ \\
\hline
\end{tabular}

mitted to stand at room temperature for $40 \mathrm{~min}$ utes, by which time complete coagulation had occurred. The clot was then gently loosened and the serum obtained by centrifugation. So close an agreement was obtained between the iron content of the serum specimens prepared in these two ways (Table VIII) that it has been possible

TABLE VIII

Comparison of the non-hemoglobin iron content of serum prepared by: I. Immediate centrifugation and separation from the formed elements; and II. Centrifugation after complete coagulationy of the whole blood.

\begin{tabular}{|c|c|c|c|c|c|c|c|}
\hline \multirow{2}{*}{ Subject } & \multicolumn{3}{|c|}{$\begin{array}{l}\text { Serum obtained } \\
\text { by immediate } \\
\text { centrifugation }\end{array}$} & \multicolumn{3}{|c|}{$\begin{array}{l}\text { Serum obtained after } \\
\text { complete coagulation } \\
\text { of the whole blood } \\
\text { (40 minutes after } \\
\text { venesection) }\end{array}$} & \multirow{2}{*}{$\begin{array}{l}\text { Va- } \\
\text { ria- } \\
\text { tion }\end{array}$} \\
\hline & $\begin{array}{c}\text { Total } \\
\text { iron } \\
\text { pres- } \\
\text { ent }\end{array}$ & $\begin{array}{c}\text { Hemo- } \\
\text { glo- } \\
\text { bin } \\
\text { iron }\end{array}$ & $\begin{array}{c}\text { Non- } \\
\text { hemo- } \\
\text { globin } \\
\text { iron }\end{array}$ & $\begin{array}{l}\text { Total } \\
\text { iron } \\
\text { pres- } \\
\text { ent }\end{array}$ & $\begin{array}{c}\text { Hemo- } \\
\text { glo- } \\
\text { bin } \\
\text { iron }\end{array}$ & $\begin{array}{c}\text { Non- } \\
\text { hemo- } \\
\text { globin } \\
\text { iron }\end{array}$ & \\
\hline \multirow{3}{*}{ 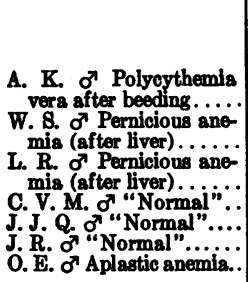 } & $\begin{array}{c}\operatorname{mom} . \\
\text { per } \\
\text { cent }\end{array}$ & $\begin{array}{c}\text { mom. } \\
\text { per } \\
\text { cent }\end{array}$ & $\begin{array}{c}\text { mom. } \\
\text { per } \\
\text { cent }\end{array}$ & $\begin{array}{c}\text { mom. } \\
\text { per } \\
\text { cent }\end{array}$ & $\begin{array}{l}\text { mom. } \\
\text { per } \\
\text { cent }\end{array}$ & $\begin{array}{c}\text { mom. } \\
\text { per } \\
\text { cent }\end{array}$ & $\begin{array}{l}\text { per } \\
\text { cent }\end{array}$ \\
\hline & $\begin{array}{l}0.022 \\
0.057\end{array}$ & $\left|\begin{array}{l}<0.001 \\
<0.001\end{array}\right|$ & $\begin{array}{l}0.022 \\
0.057\end{array}$ & $\begin{array}{l}0.022 \\
0.057\end{array}$ & $\begin{array}{l}<0.001 \\
<0.001\end{array}$ & $\left|\begin{array}{l}0.022 \\
0.057\end{array}\right|$ & $\begin{array}{l}0 \\
0\end{array}$ \\
\hline & $\begin{array}{l}0.060 \\
0.098 \\
0.117 \\
0.158 \\
0.163\end{array}$ & $\begin{array}{r}<0.001 \\
<0.001 \\
<0.001 \\
<0.001 \\
0.001\end{array}$ & $\begin{array}{l}0.060 \\
0.098 \\
0.117 \\
0.158 \\
0.162\end{array}$ & $\begin{array}{l}0.057 \\
0.096 \\
0.123 \\
0.150 \\
0.166\end{array}$ & $\begin{array}{r}<0.001 \\
<0.001 \\
0.004 \\
<0.001 \\
0.001\end{array}$ & $\begin{array}{l}0.057 \\
0.096 \\
0.119 \\
0.150 \\
0.165\end{array}$ & $\begin{array}{l}-5.0 \\
-2.0 \\
+1.7 \\
-5.3 \\
+2.0\end{array}$ \\
\hline
\end{tabular}

to conclude that non-hemoglobin iron is not increased in serum in appreciable amounts when whole blood coagulates.

\section{Summary}

Evidence which tends to establish plasma or serum iron as of non-hemoglobinous origin has been presented. Reference to four different chemical methods by which the iron in sera may accurately be determined has been made, and a detailed description of the colorimetric thiocyanate technique used in these studies has been given. The normal zonal range for human plasma iron was found to be approximately 0.050 to 0.180 mgm. per cent. The average value for normal men proved to be slightly higher than the average for normal women. No essential difference in the plasma and serum iron values was detected.

The chemical relationships and nature of serum iron are not well understood. It is known that serum iron does not pass through a semi-permeable membrane unless altered as by acidification $(1, g)$; the iron, therefore, is not in an ionized state. It may be present as a component of a complex radical. Starkenstein and Harvalik (46) believe it to be in combination with the protein of the serum, and, more specifically, with globulin. Little doubt remains that the iron in serum is in the trivalent state (46).

\section{B. "EASILY SPLIT-OFF" BLOOD IRON}

Barkan $(1, a, b)$ and Lintzel $(2, a)$, working independently, each made the observation that when whole blood is subjected to the action of various of the digestive ferments, approximately 5 to 10 per cent of the blood iron is changed to an ionized form. They later discovered that the same "splitting-off" action is exerted either by dilute acids or by dilute bases alone. Lintzel and Radeff $(2, b)$ were able to "split-off" this ionizable iron from preparations of crystalline hemoglobin and came to believe that the metal was derived directly from the dissociation of the hemoglobin molecule. Barkan repeated Lintzel's observations, but on one occasion $(1, b)$ obtained a preparation of crystalline hemoglobin, preserved constantly under alcohol, from which only traces of iron could be dissociated or "split-off" by dilute hydrochloric acid. This and other data led him to believe that "das leicht abspaltbare Bluteisen" fraction constituted a third type of blood iron, distinct from either hemoglobin or plasma iron. In subsequent well controlled, well directed researches, Barkan $(1, c)$ has attempted further to establish the identity of " easily splitoff" iron and has tentatively ascribed to it the 
function of iron transportation in the blood stream $(1, l)$.

That some 5 to 10 per cent of the iron in blood is ionized by dilute acids, there can be no doubt. It is not as yet certain, however, that the " easily split-off " fraction is a non-hemoglobinous form of blood iron even though it must be admitted that the experimental evidence accumulated by Barkan points definitely to that conclusion.

It is unfortunately true that "the precise ascertainment of the $\mathrm{Fe}$ content of purified human hemoglobin is a problem that awaits solution" (Peters and Van Slyke (27)). Nevertheless, a close approximation to that content has probably been obtained by Hüfner (28) and by Morrison and Hisey (29) who found that hemoglobin contained 0.34 per cent iron. With the use of this figure, it is possible to calculate from the whole blood iron that amount of hemoglobin which would be present per unit of peripheral blood if all of the iron were present in hemoglobinous combination. ${ }^{4}$ The calculated hemoglobin value, then, might be compared with that obtained by actual determination with either oxygen capacity or acid hematin methods. If there should be agreement between the determined and the calculated hemoglobin values, it would be fair to assume that all of the blood iron (except that present in the serum) is hemoglobin iron. Such an agreement would constitute presumptive evidence that the " easily split-off" iron is dissociated from the hemoglobin molecule per se. If, on the other hand, it should be found that more iron is present in the blood stream than can be accounted for by the hemoglobin present, then it would seem that Barkan's point of view would be substantiated, and "easily split-off" iron would have to be considered a form of non-hemoglobin blood iron. As a matter of fact, many such comparisons have been made. Most observers (12, 30 to 36 ) have obtained agreements of 1 per cent or less between calculated and determined hemoglobin values. But Klumpp (38), using the oxygen capacity gasometric method for the determination of hemoglobin, and Josephs (39), using an acid hematin method, found more iron present in the

\footnotetext{
4 The serum iron is relatively so small that it may, for the sake of convenience, be omitted from the present consideration.
}

blood stream than would have been the case had it all been present as a component of the hemoglobin molecule. Until more definite agreement is attained, therefore, no conclusions may be drawn from this type of reasoning.

"Easily split-off" blood iron has been determined in several ways. Barkan (40) acidified whole blood with 0.8 per cent hydrochloric acid, incubated it for 24 hours at $37.5^{\circ} \mathrm{C}$., and then passed it through an ultrafilter, using a collodion membrane. He showed that the ionization or "splitting-off" process was not immediate, but that it was practically complete at the end of 24 hours. Dominici (4) and Starkenstein and Weden (3) heated hydrochloric acidified whole blood to boiling and then precipitated the proteins with trichloracetic acid. Winegarden and Borsook (41) obtained the fraction by placing $5 \mathrm{cc}$. of blood and $5 \mathrm{cc}$. of $0.2 \mathrm{~N} \mathrm{HCl}$ in cellophane bags and dialyzing against $0.1 \mathrm{~N} \mathrm{HCl}$ at $37.5^{\circ} \mathrm{C}$. for 24 hours, changing the outside acid once at the end of 6 to 8 hours. Olesk (43) and Schwarz and Deckert (42), using the ultrafiltration method, obtained values which are in close agreement with those of Barkan. Dominici (4) made the interesting observation that $0.1 \mathrm{~N} \mathrm{H}_{2} \mathrm{SO}_{4}$ will "split-off" considerably more iron than $0.1 \mathrm{~N}$ $\mathrm{HCl}$.

The method employed in this study is similar to the one used by Winegarden and Borsook. Cellophane tubing was cut in 12 inch lengths and washed for 24 hours in iron-free $0.2 \mathrm{~N} \mathrm{HCl}$. Each end of the cellophane strip was then slipped over a short section of glass tube $(13 \mathrm{~mm}$. diameter, 2 inches long), made fast with a rubber band, and the whole washed with iron-free water. Into one of the open ends, $5 \mathrm{cc}$. of whole oxalated blood and $5 \mathrm{cc}$. of $0.2 \mathrm{~N} \mathrm{HCl}$ were pipetted. The membrane was then suspended in a $250 \mathrm{cc}$. beaker containing $100 \mathrm{cc} .0 .1 \mathrm{~N} \mathrm{HCl}$. The dialysis was carried out at $37.5^{\circ} \mathrm{C}$. At 24 hour intervals for 4 days, the outside $\mathrm{HCl}$ was removed and replaced by a fresh $100 \mathrm{cc}$. At the end of the dialyzing period, the total amount of $\mathrm{HCl}$ which had been used outside the membrane was made up to a volume of $500 \mathrm{cc}$. Aliquot portions of this were digested in Kjeldahl flasks and the iron determinations completed in a manner similar to that described for the determination of plasma or serum iron. Under these conditions, only about 
65 to 75 per cent of the ionized iron was obtained after a 24 hour period of dialysis; over 95 per cent was dialyzed in 4 days. Detectable, but very small amounts of iron could be obtained in the $\mathrm{HCl}$ surrounding the membrane for 2 or 3 days more. The method was standardized, however, for a 4 day dialyzing period.

The average value obtained by Barkan on twenty-two human subjects in Frankfort was 1.42 mgm. per cent. Schwarz and Deckert (42), working in Hamburg, found a variation of from $1.26 \mathrm{mgm}$. per cent to $1.68 \mathrm{mgm}$. per cent with an average of $1.47 \mathrm{mgm}$. per cent. Olesk (43) working in Barkan's laboratory in Esthonia, observed an average value of $1.85 \mathrm{mgm}$. per cent on 73 subjects, with range extremes of 1.39 to 2.23 mgm. per cent. He reported that the average figure for males was slightly higher than the average for females. Dominici (4), however, using sulfuric instead of hydrochloric acid, noted a variation from 0.92 to $3.12 \mathrm{mgm}$. per cent on twelve subjects, and obtained an average of $2.22 \mathrm{mgm}$. per cent. This last observation by Dominici to the effect that greater amounts of iron are "splitoff " by sulfuric than by hydrochloric acid led us to make determinations of the " easily split-off" iron fraction on the same sample of blood using different acids in several concentrations. In Table IX are recorded several such experiments in which hydrochloric, sulfuric, and nitric acids were
TABLE IX

"Easily split-off" blood iron as determined with varying concentrations of different mineral acids

\begin{tabular}{|c|c|c|c|c|c|c|c|c|}
\hline \multirow{2}{*}{ Sub- } & \multicolumn{4}{|c|}{$\mathrm{HCI}$} & \multicolumn{2}{|c|}{$\mathrm{H}_{2} \mathrm{SO}$, } & \multicolumn{2}{|c|}{$\mathrm{HNO}_{3}$} \\
\hline & $0.05 \mathrm{~N}$ & $0.1 \mathrm{~N}$ & $0.2 \mathrm{~N}$ & $0.35 \mathrm{~N}$ & $0.1 \mathrm{~N}$ & $0.2 \mathrm{~N}$ & $0.1 \mathrm{~N}$ & $0.2 \mathrm{~N}$ \\
\hline & $\begin{array}{c}\text { mgm. } \\
\text { per } \\
\text { cent }\end{array}$ & $\begin{array}{c}\text { mgm. } \\
\text { per } \\
\text { cent }\end{array}$ & $\begin{array}{c}\text { mgm. } \\
\text { per } \\
\text { cent }\end{array}$ & $\begin{array}{c}\text { mgm. } \\
\text { per } \\
\text { cent }\end{array}$ & $\begin{array}{c}\text { mgm. } \\
\text { per } \\
\text { cent }\end{array}$ & $\begin{array}{c}\text { mgm. } \\
\text { per } \\
\text { cent }\end{array}$ & $\begin{array}{c}\text { mgm. } \\
\text { per } \\
\text { cent }\end{array}$ & $\begin{array}{c}\text { mgm. } \\
\text { per } \\
\text { cent }\end{array}$ \\
\hline $\begin{array}{l}\text { C. V. M.... } \\
\text { W. R. A.... } \\
\text { J. J. Q..... } \\
\text { P. B....... } \\
\text { H. W..... }\end{array}$ & $\begin{array}{l}3.300 \\
1.851 \\
2.740\end{array}$ & $\begin{array}{l}2.190 \\
1.623 \\
2.714 \\
1.712 \\
2.362\end{array}$ & $\begin{array}{l}1.841 \\
1.238 \\
1.515 \\
1.562 \\
2.069\end{array}$ & $\begin{array}{l}1.623 \\
1.000 \\
1.316\end{array}$ & \begin{tabular}{|l|}
3.614 \\
3.061 \\
3.822 \\
2.608 \\
3.658
\end{tabular} & $\begin{array}{l}3.614 \\
3.061 \\
4.028 \\
2.631 \\
3.691\end{array}$ & $\begin{array}{l}3.846 \\
3.158 \\
3.750\end{array}$ & $\begin{array}{l}3.670 \\
3.530\end{array}$ \\
\hline
\end{tabular}

used. It is immediately apparent that: 1, sulfuric and nitric acids "split-off" approximately the same amount of iron, an amount that is considerably greater than that "split-off" by hydrochloric acid; 2 , sulfuric and nitric acids dissociate or ionize approximately the same amounts of iron whether used in concentrations of 0.1 or $0.2 \mathrm{~N}$; and 3 , increasing the concentration of hydrochloric acid tends to decrease, rather than to increase, the amount of iron it dissociates.

" Easily split-off" iron values on twenty " normal " human subjects were determined with both $0.1 \mathrm{~N} \mathrm{HCl}$ and $0.1 \mathrm{~N} \mathrm{H}_{2} \mathrm{SO}_{4}$ according to the method of dialysis described above. The results, together with the pertinent hematological data, are tabulated in Table $\mathrm{X}$. The values are somewhat higher than those reported by the various European workers. With $0.1 \mathrm{~N} \mathrm{HCl}$, for instance, an

TABLE $\mathrm{X}$

"Easily split-off" iron content of " normal" human blood

\begin{tabular}{|c|c|c|c|c|c|c|c|c|c|c|c|}
\hline \multicolumn{6}{|c|}{ Males } & \multicolumn{6}{|c|}{ Females } \\
\hline \multirow{2}{*}{$\begin{array}{l}\text { Sub- } \\
\text { jects }\end{array}$} & \multicolumn{3}{|c|}{ Hematological data } & \multicolumn{2}{|c|}{ "Easily split-off" iron } & \multirow{2}{*}{ Sub- } & \multicolumn{3}{|c|}{ Hematological data } & \multicolumn{2}{|c|}{ "Easily split-off" iron } \\
\hline & R.B.C. & Hb. & $\begin{array}{l}\text { Cell } \\
\text { vol- } \\
\text { ume }\end{array}$ & $0.1 \mathrm{~N} \mathrm{HCl}$ & $0.1 \mathrm{~N} \mathrm{H}_{2} \mathrm{SO}_{4}$ & & R.B.C. & Hb. & $\begin{array}{l}\text { Cell } \\
\text { vol- } \\
\text { ume }\end{array}$ & $0.1 \mathrm{~N} \mathrm{HCl}$ & $0.1 \mathrm{~N} \mathrm{H}_{2} \mathrm{SO}_{4}$ \\
\hline 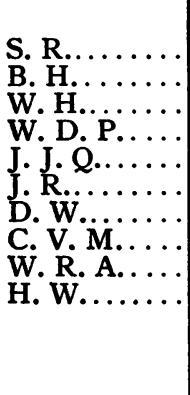 & $\begin{array}{c}\text { millions } \\
5.22 \\
4.54 \\
4.90 \\
5.16 \\
5.85 \\
4.92 \\
4.42 \\
5.21 \\
4.86 \\
3.89\end{array}$ & $\begin{array}{c}\text { grams } \\
15.6 \\
16.5 \\
16.3 \\
15.0 \\
16.4 \\
15.2 \\
14.8 \\
15.6 \\
14.3 \\
13.9 \\
\text { Mini } \\
\text { Max } \\
\text { Aver }\end{array}$ & $\begin{array}{c}\text { per cent } \\
44.0 \\
47.4 \\
40.0 \\
44.0 \\
46.5 \\
44.5 \\
40.2 \\
45.2 \\
42.0 \\
41.0 \\
\text { mum } \\
\text { imum } \\
\text { age }\end{array}$ & $\begin{array}{c}\text { mgm. per cent } \\
2.186 \\
2.167 \\
2.286 \\
2.613 \\
2.600 \\
2.190 \\
2.884 \\
2.076 \\
1.499 \\
2.362 \\
1.499 \\
2.884 \\
2.286\end{array}$ & \begin{tabular}{|c|} 
mgm. per cent \\
4.397 \\
4.340 \\
3.707 \\
4.111 \\
3.708 \\
4.026 \\
4.142 \\
3.500 \\
2.947 \\
3.658 \\
2.947 \\
4.397 \\
3.854
\end{tabular} & 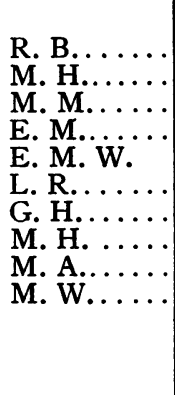 & $\begin{array}{c}\text { millions } \\
4.61 \\
4.47 \\
4.32 \\
4.69 \\
5.13 \\
4.42 \\
4.66 \\
3.80 \\
4.56 \\
4.02\end{array}$ & $\begin{array}{c}\text { grams } \\
12.5 \\
14.1 \\
13.2 \\
13.5 \\
9.7 \\
13.3 \\
11.7 \\
12.0 \\
12.8 \\
12.2 \\
\text { Mini } \\
\text { Max } \\
\text { Aver }\end{array}$ & $\begin{array}{c}\text { per cent } \\
44.0 \\
40.0 \\
38.0 \\
41.5 \\
32.5 \\
40.0 \\
37.0 \\
37.8 \\
38.0 \\
36.5 \\
\text { mum } \\
\text { imum } \\
\text { age }\end{array}$ & $\begin{array}{c}\text { mgm. per cent } \\
3.154 \\
2.520 \\
1.963 \\
2.934 \\
2.497 \\
2.841 \\
2.108 \\
2.301 \\
2.676 \\
2.305 \\
1.963 \\
3.154 \\
2.530\end{array}$ & $\begin{array}{c}\text { mgm. per cent } \\
4.786 \\
4.318 \\
4.436 \\
4.634 \\
4.334 \\
4.859 \\
3.576 \\
3.849 \\
4.671 \\
4.366 \\
3.576 \\
4.786 \\
4.283\end{array}$ \\
\hline
\end{tabular}


average figure of $2.408 \mathrm{mgm}$. per cent was obtained, and the range extended from 1.499 to $3.154 \mathrm{mgm}$. per cent. The only investigator who has used sulfuric acid is Dominici, and his technique is not strictly comparable to the one used here. The " easily split-off" iron determinations made with $0.1 \mathrm{~N}$ sulfuric acid averaged 4.068 mgm. per cent and varied from 2.947 to 4.786 mgm. per cent.

Barkan and Berger $(1, e)$ also observed that approximately 60 to 70 per cent of the "easily split-off" iron fraction is bound by $\mathrm{CO}$ in such a manner that it is protected against the "splitting-off" action of acids. The whole of this sub-fraction " $E$ " is contained in the erythrocytes and is reported to have greater affinity for $\mathrm{CO}$ than does hemoglobin, i.e., with partial saturation of the blood, the gas unites with a greater per cent of " easily split-off" iron than with hemoglobin. Schwarz and Deckert (42) and Olesk (43) have noted that the $\mathrm{CO}$ absorbed by heavy smokers is sufficient to bind a portion of the "easily splitoff" iron, and caution that such determinations should be made after a period of "tobacco-fasting." The 30 to 40 per cent " easily split-off" iron not bound by $\mathrm{CO}$ has been termed $(1, e)$ the $\mathrm{E}^{\prime}$ sub-fraction and has been observed to be present in both the red cells and in plasma (all of the iron in plasma is determined as a part of this $\mathrm{E}^{\prime}$ portion).

Tompsett (11) with a thioglycollic acid method and McIntosh (44) by precipitating whole blood with trichloracetic acid attempted to determine the inorganic iron of whole blood and obtained values of about $1.0 \mathrm{mgm}$. per cent. It is difficult, of course, to know how much of the so-called inorganic iron fraction which McIntosh measured was carried down with the protein precipitate as has been shown to occur with plasma iron (Tables II and III). Barkan $(1, i)$ has presented evidence to show that the "easily split-off" blood iron is not an inorganic form of iron.

\section{SUMMARY}

A satisfactory understanding of the chemical nature of " easily split-off" blood iron has not as yet been attained. Certain it is that approximately 5 to 10 per cent of whole blood iron is "split-off" or dissociated from its usual combination by the action of dilute acids. With the method of dialysis used in these investigations, we have found the average value of this fraction on twenty " normal " subjects to be approximately 2.3 to $2.5 \mathrm{mgm}$. per cent when acidification was accomplished with $0.1 \mathrm{~N} \mathrm{HCl}$. The figures extended from $1.499 \mathrm{mgm}$. per cent to $3.154 \mathrm{mgm}$. per cent. When sulfuric (or nitric) acid was substituted for hydrochloric, however, the values obtained were somewhat higher and ranged from 2.947 to $4.786 \mathrm{mgm}$. per cent. The significance of the greater "splitting-off" ability of sulfuric and nitric acids is not as yet entirely clear. There are no strictly comparable values in the literature with which those of the iron " easily split-off" by sulfuric acid may be compared. Those workers who have used hydrochloric acid and Barkan's method of ultrafiltration have obtained range extremes of from 1.2 to $2.23 \mathrm{mgm}$. per cent on " normal" human subjects.

"Easily split-off" iron may be a form of nonhemoglobin blood iron, as Barkan believes, but further proof is necessary before we may accept this fraction as composed of iron unassociated with the hemoglobin molecule. Since evidence has accumulated which tends to show that there is more than one kind of hemoglobin in human blood (45)-and, possibly, in the blood of animals as well-, the question naturally arises as to what relationship, if any, "easily split-off" iron may have to the hemoglobin form or forms which may be present in relatively small concentration. Barkan and Schales $(1, n)$ have pointed out that since "easily split-off" iron and hemoglobin react similarly to adsorption on argillaceous earths and to cataphoresis, and since both combine readily with carbon monoxide, the two molecules are probably closely related structurally. Dilute acids do ionize or " split-off" a certain proportion of the whole blood iron, but identification of the molecule from which this dissociation takes place is yet to be accomplished.

\section{CONCLUSIONS}

I. Plasma or serum iron

$A$. Plasma or serum iron is a non-hemoglobinous form of blood iron.

$B$. Various methods for the determination of plasma iron have been described, the most satisfactory of these being the colorimetric method which 
determines the iron present as ferric thiocyanate in an amyl alcohol solution.

C. The normal zonal range for human plasma iron is approximately 0.050 to $0.180 \mathrm{mgm}$. per cent. The average value for men is slightly higher than the average for normal women.

$D$. Plasma and serum iron values are essentially identical.

II. "Easily split-off" blood iron

$A$. When whole blood is acidified, 5 to 10 per cent of the total iron present becomes ionized so that it will pass through a semipermeable membrane.

$B$. With Barkan's method of ultrafiltration through a collodion membrane after acidification of the blood with 0.8 per cent $\mathrm{HCl}$ and incubation at body temperature for 24 hours, the amount of " easily split-off" iron in normal human subjects has been found to vary from 1.2 to 2.25 mgm. per cent. With hydrochloric acidification and the method of dialysis (through a cellophane membrane) used in these studies, a range for " easily split-off" blood iron of from 1.499 to $3.154 \mathrm{mgm}$. per cent was obtained on twenty " normal" human subjects.

C. Sulfuric and nitric acids "split-off" considerably more iron than does hydrochloric acid (range 2.947 to 4.786 mgm. per cent). Values obtained with sulfuric and nitric acidification are in close agreement.

$D$. With increases in concentration of hydrochloric acid, the amount of iron "split-off" progressively decreases. Changes in concentration from 0.1 to $0.2 \mathrm{~N}$ sulfuric or nitric acids did not alter the values obtained.

$E$. The work of Barkan points to the conclusion that "easily split-off" iron is an organic, non-hemoglobinous form of iron, but further proof is needed before we may accept the fraction as being unassociated with the hemoglobin molecule.

III. The further validity of these conclusions has been suggested by the application of the above principles in selected clinical cases which are being presented coincidently.

\section{BIBLIOGRAPHY}

1. Barkan, G.,

(a) Eisenstudien. I. Zur Frage der Einwirkung von Verdauungsfermenten auf das Hämoglobineisen. Ztschr. f. physiol. Chem., 1925, 148, 124.

(b) II. Uber das leicht abspaltbare Bluteisen und sein Varhältnis zum Hämoglobin. Ztschr. f. physiol. Chem., 1927, 171, 179.

(c) III. Die Verteilung des leicht abspaltbaren Eisens zwischen Blutkörperchen und Plasma und sein Verhalten unter experimentellen Bedingungen. Ztschr. f. physiol. Chem., 1927, 171, 194.

(d) Ubber Säurelösliches Eisen im Blutserum. Klin. Wchnschr., 1927, 6, 1615.

$(e)$ and Berger, E., Differenzierung des leicht abspaltbaren Bluteisens auf Grund seiner Reaktion mit Kohlenoxyd und Sauerstoff. Arch. f. exper. Path. u. Pharmakol., 1928, 136, 278.

(f) Zur Frage des Blutfarbstoffzerfalls durch verdünnte Säuren. Biochem. Ztschr., 1930, 224, 53.

(g) VI. Uber Bestimmungsmethodik und Eigenschaften des "leicht abspaltbaren" Bluteisens. Ztschr. f. physiol. Chem., 1933, 216, 1.

(h) VII. Utber das Verhalten von anorganischem Eisen nach Zusatz zum Blute. Ztschr. f. physiol. Chem., 1933, 216, 17.

(i) VIII. Die Unterscheidung des "leicht abspaltbaren" Bluteisens vom Hämoglobineisen und vom anorganischen Eisen. Ztschr. f. physiol. Chem., 1933, 221, 241.

(j) Neuere Untersuchungen über das Bluteisen. Forsch. u. Fortschr., 1934, 10, 114.

(k) IX. Zur Frage der Identität der Blutkatalase mit dem leicht abspaltbaren Bluteisen. Ztschr. f. physiol. Chem., 1935, 236, 97.

(l) X. Weitere Untersuchungen über das säurelösliche Plasmaeisen. Ztschr. f. physiol. Chem., 1936, 239, 97.

$(m)$ and Schales, O., XI. Trennung der Blutkatalase vom "leicht abspaltbaren" Eisen. Ztschr. f. physiol. Chem., 1936, 244, 81.

$(n)$ and Schales, O., XII. Hämoglobin und "leicht abspaltbares" Eisen bie der Adsorption und bie der Kataphorese. Ztschr. f. physiol. Chem., 1936, 244, 257.

2. Lintzel, W.,

(a) Zur Frage des Eisenstoffwechsels. I. Das Verhalten des Blutfarbstoffes bei Künstlicher Verdauung. Ztschr. f. Biol., 1925, 83, 289.

(b) and Radeff, T., Uber die Hämatinbildung aus $\mathrm{CO}-\mathrm{Hämoglobin}$ und Oxyhämoglobin durch 
verdünnte Säuren. Biochem. Ztschr., 1928, 203, 212.

3. Starkenstein, E., and Weden, $H$., Utber das anorganische Eisen des Organismus. Arch. f. exper. Path. u. Pharmakol., 1928, 134, 274.

4. Dominici, G., La determinazione quantitativa del ferro inorganico del sangue. Arch. per le sc. med., 1929, 53, 538.

5. Shorland, F. B., and Wall, E. M., The action of certain reagents on the "loosely bound" iron in blood. Biochem. J., 1936, 30, 1049.

6. Henriques, V., and Roche, A., Sur le Fer du sérum Sangúin de diverses Espéces animales. Bull. Soc. chim. biol., 1927, 9, 501.

7. Marlow, A., and Taylor, F. H. L., Constancy of iron in the blood plasma and urine in health and in anemia. Arch. Int. Med., 1934, 53, 551.

8. Fowweather, F. S., The determination of iron in blood plasma. Biochem. J., 1934, 28, 1160.

9. Bing, F. C., and Hanzal, R. F., A method for the estimation of serum iron. Proc. Soc. Exper. Biol. and Med., 1935, 32, 1013.

10. Leiboff, S. L., The detection of blood by means of benzidine dihydrochloride. J. Lab. and Clin. Med., 1928, 14, 1187.

11. Tompsett, S. L., Thiolacetic acid as a reagent for the determination of the inorganic iron content of certain biological materials. Biochem. J., 1934, 28, 1536.

12. Kennedy, R. P., The quantitative determination of iron in tissues. J. Biol. Chem., 1927, 74, 385.

13. West, E. S., Improved laboratory condenser and its use in the construction of apparatus. Indust. and Engin. Chem., Anal. Ed., 1930, 2, 199. (Obtained from Arthur H. Thomas Co., Philadelphia.)

14. Farrar, George E., Jr., The determination of iron in biological materials. J. Biol. Chem., 1935, 110, 685.

15. Winter, O. B., The determination of iron. J. Ass. Off. Agric. Chem., 1931, 14, 216.

16. Stugart, R., Determination of iron in milk and other biological materials. Indust. and Engin. Chem., Anal. Ed., 1931, 3, 390.

17. Ascham, Leah, A colorimetric iron method for biological materials. J. Home Economics, 1931, 23, 776.

18. Fontès, G., and Thivolle, L., Sur la Teneur du Sérum en Fer non Hémoglobinique et sur sa Diminution au Cours de l'Anémie Expérimentale. Compt. rend. Soc. de biol., 1925, 93, 687.

19. Warburg, O., and Krebs, H. A., Uber locker gebundenes Kupfer und Eisen im Blutserum. Biochem. Ztschr., 1927, 190, 143.

20. Abderhalden, E., and Möller, P., Untersuchungen über den Gehalt des Blutserums an Eisen, Kupfer, und Mangan. Ztschr. f. physiol. Chem., 1928, 176, 95.

21. Riecker, H. H.,

(a) Iron metabolism in pernicious and secondary anemia. Arch. Int. Med., 1930, 46, 458. (b) and Winters, M. E., Serum iron determinations applied to the study of experimental anemia. Am. J. Physiol., 1930, 92, 196.

22. Langer, A., Über den Gehalt an Ferrieisen in normalen und pathologischen Seren. Biochem. Ztschr., 1931, 242, 316.

23. Guthmann, H., Brückner, M. A., Ehrenstein, and Wagner, H., Das ultrafiltrable Eisen im Serum der Frau (Biologische und klinische Studien). Arch. f. Gynäk., 1931, 147, 469.

24. Locke, A., Main, E. R., and Rosbash, D. O., The copper and non-hemoglobinous iron contents of the blood serum in disease. J. Clin. Invest., 1932, 11, 527.

25. Thoenes, F., and Aschaffenburg, R., Der Eisenstoffwechsel des wachsenden organismus. S. Karger, Berlin, 1934.

26. Roosen-Runge, E., Beitrag zur Methodik der Bestimmung des "leicht abspaltbaren" Eisens im Serum und einige klinische Ergebnisse. Klin. Wchnschr., 1935, 14, 1540.

27. Peters, J. P., and Van Slyke, J. J., Quantitative Clinical Chemistry, Vol. I. Interpretations. Williams and Wilkins Co., Baltimore, 1931.

28. Hüfner, G., Neue Versuche zur Bestimmung der Sauerstoffcapacität des Blutfarbstoffs. Arch. f. Anat. u. Physiol., 1894, p. 130.

29. Morrison, D. B., and Hisey, A., The carbon monoxide capacity, iron and total nitrogen of dog hemoglobin. J. Biol. Chem., 1935, 109, 233.

30. Abt, Arthur F., Anemia of premature infants. II. A comparative study of blood iron and hemoglobin values in premature infants. Am. J. Dis. Child., 1935, 49, 1204.

31. Johnson, Martha, and Hanke, M. E., The iron content and oxygen capacity of blood. J. Biol. Chem., 1936, 114, 157.

32. Sobel, I. P., and Drekter, I. J., Determination of the iron content of the blood in children. Am. J. Dis. Child., 1933, 45, 486.

33. Dowden, C. W., and McNeill, J. S., A clinical study of blood iron and hemoglobin. J. Lab. and Clin. Med., 1934, 19, 362.

34. Lindsay, J. W., Rice, E. C., and Selinger, M. A., A plea for a standardized method of estimating and reporting hemoglobin values. J. Lab. and Clin. Med., 1926, 11, 737.

35. Haden, R. L., The determination of hemoglobin by the iron content method. J. Lab. and Clin. Med., $1934,19,406$.

36. Helmer, O. M., and Emerson, Charles P., Jr., The iron content of the whole blood of normal individuals. J. Biol. Chem., 1934, 104, 157.

37. Butterfield, E. E., Uber die Lichtextinkion, das Gasbindungsvermögen und den Eisengehalt des menschlichen Blutfarbstoffs in normalen und krankhaften Zuständen. Ztschr. f. physiol. Chem., 1909, 62, 173.

38. Klumpp, Theodore G., The variability of non-hemoglobin iron. J. Clin. Invest., 1935, 14, 351. 
39. Josephs, H. W., The iron of the blood. A comparison of values for haemoglobin determined by the Newcomer method and calculated from the iron content. Bull. Johns Hopkins Hosp., 1935, 56, 50.

40. Barkan, G., Verfahren zur Bestimmung des "leicht abspaltbaren" Bluteisens. Abderhalden, E., Handb. d. biol. Arbeitsmethoden, 1935, 5, No. 8, 1207. Verlag von Urban und Schwarzenberg, Berlin.

41. Winegarden, H. M., and Borsook, H., On the spectrophotometric differentiation of the hemoglobins of different species. J. Cell. and Comp. Physiol., 1933, 3, 437.

42. Schwarz, L., and Deckert, W., Uber leicht abspalt- bares Bluteisen bei Vergiftungen und anderen Krankheiten. Klin. Wchnschr., 1935, 14, 601.

43. Olesk, J., Uber den normalgehalt an "leicht abspaltbarem" Eisen im Blute des Menschen. Klin. Wchnschr., 1935, 14, 1006.

44. McIntosh, J. F., The nonprotein iron of the blood. J. Clin. Invest. (Proc.), 1933, 12, 967.

45. Brinkman, R., and Jonxis, J. H. P., The occurrence of several kinds of hemoglobin in human blood. J. Physiol., 1935, 85, 117.

46. Starkenstein, E., and Harvalik, Z., Uber eine im intermediären Eisenstoff wechsel entstehende Ferriglobulinverbindung. Arch. f. exper. Path. u. Pharmakol., 1933, 172, 75. 